\title{
A chemically and texturally distinct layer of diamondiferous eclogite beneath the central Slave craton, northern Canada.
}

\author{
Cookenboo, H. O. ${ }^{1}$, Kopylova, M. G. ${ }^{2}$ and Daoud, D.K. ${ }^{1}$
}

1. Canamera Geological Ltd., 399 Mountain Highway, North Vancouver, British Columbia Canada V7J 2K9

2. Geological Sciences Division, Department of Earth and Ocean Sciences, The University of British Columbia, Vancouver, British Columbia, Canada V6T 1 Z4

Diamond bearing eclogites between 0.5 and $5 \mathrm{~cm}$ across have been recovered from the Jericho kimberlite in northern Canada. Garnet and clinopyroxene from nine xenoliths have similar textures and a tightly restricted compositional range, suggesting they were all derived from a single diamondiferous eclogite layer underlying this part of northern Canada. This paper describes the texture and chemistry of the Jericho diamondiferous eclogites, and discusses their implications to: 1) mantle stratigraphy beneath the central Slave craton; and 2) kimberlite exploration in the area.

\section{Texture and chemistry:}

The nine analyzed xenoliths from Jericho differ both texturally and chemically from other eclogites in the pipe. These diamondiferous eclogites have a massive texture composed of coarse (3 to $10 \mathrm{~mm}$ ) anhedral orange garnet and light green clinopyroxene crystals, commonly with $120^{\circ}$ grain intersections between grains. Distinct mineral foliation or banding is lacking in the diamondiferous eclogites, although it is pervasive in most eclogites from Jericho, and the clinopyroxene to garnet ratio is roughly even.

Most of the garnets and clinopyroxene crystals are surrounded by coats of Ti-phlogopite, Al-poor tetraferriphlogopite, and minor secondary calcite, serpentine, barite and apatite associated with the kimberlite magma occurs on fractures and between grains. Chlorite alteration of clinopyroxene and kelyphitization of garnet is common. $\mathrm{Rb}-\mathrm{Sr}$ dating of phlogopite from one of these diamondiferous eclogites yielded age of $172 \mathrm{Ma}$, equal to the emplacement age determined from phlogopite megacrysts within the Jericho kimberlite. The radiometric age and mineralogy of the secondary minerals (including phlogopite), implies that interaction with kimberlite-related fluids led to alteration of these eclogites.

Chemically, both the garnets and clinopyroxene are distinct from other eclogites at Jericho. The most notable chemical features of the eclogitic garnets are their high concentrations of $\mathrm{MgO}$ (19.4 to $21.3 \% \mathrm{MgO}$ ) and their low and remarkably constant concentration of $\mathrm{CaO}$, which only varies between 4.01 to $4.30 \% \mathrm{CaO}$ for all 27 garnet analyses from the nine eclogites. By comparison, the non-diamondiferous eclogites from Jericho have a broad range of compositions (Fig. 1). The high $\mathrm{MgO}$ concentrations in garnets from the diamond bearing eclogites are more similar to $\mathrm{Cr}$-pyropes from peridotite than to most eclogitic garnets (Dawson and Stephens, 1975). The garnets, however, are typical of eclogitic garnets in being Cr-poor ( $0.2 \%$ to $\left.0.6 \% \mathrm{Cr}_{2} \mathrm{O}_{3}\right)$, Ti-poor (relative to megacryst suite garnets), and containing between 0.03 to $0.06 \% \mathrm{Na}_{2} \mathrm{O}$. The Na concentration is below the levels found in orange garnet inclusions from diamonds worldwide, which has implications for the evaluation of eclogitic garnets in till samples.

The clinopyroxene is enriched in $\mathrm{Cr}$ (between 0.11 and $\left.0.40 \% \mathrm{Cr}_{2} \mathrm{O}_{3}\right), \mathrm{Mg}(16.8$ to $17.1 \% \mathrm{MgO}$ ) and $\mathrm{Ca}(20.7$ to $21.2 \% \mathrm{CaO}$ ), compared to most non-diamondiferous eclogites at Jericho, which average $0.04 \% \mathrm{Cr} 2 \mathrm{O} 3,9.3 \% \mathrm{MgO}$, and $14.1 \% \mathrm{CaO}$ (Fig. 2). In addition, clinopyroxene from the diamondiferous eclogites are $\mathrm{Al}$-poor $\left(2.0\right.$ to $2.2 \% \mathrm{Al}_{2} \mathrm{O}_{3}$ ) and $\mathrm{Fe}$-poor ( 2.3 to $3.2 \% \mathrm{FeO}$ ), and have relatively low and constant concentrations of $\mathrm{Na}_{2} \mathrm{O}\left(1.1\right.$ to $\left.1.5 \% \mathrm{Na}_{2} \mathrm{O}\right)$ similar to Group A eclogite decribed elsewhere (Shervais, et al., 1988), compared to between 4.0 and $8.0 \% \mathrm{Na}_{2} \mathrm{O}$ in most eclogite clinopyroxene from Jericho (Fig. 2).

The restricted garnet and clinopyroxene mineral compositions comprise a distinct chemical signature for Jericho diamondiferous eclogites. Combined with the consistently massive texture, this restricted chemical signature suggests all the diamondiferous eclogites at Jericho were derived from a single 
mantle layer. Importantly for kimberlite exploration and evaluation, this chemical signature can be recognized in single garnets or clinopyroxenes from indicator mineral trains or core.

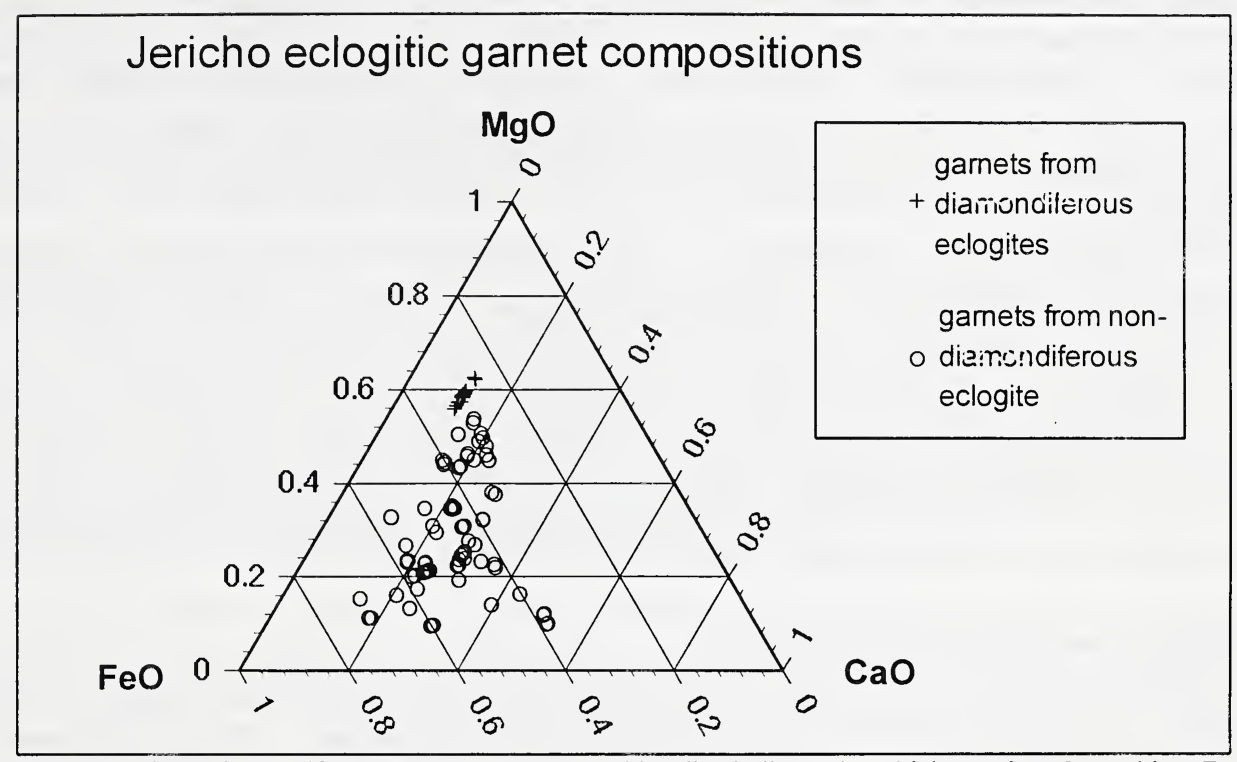

Figure 1: Garnets from diamondiferous eclogites are compositionally similar and are high-Mg, low-Ca, and low-Fe compared to other eclogites at Jericho.

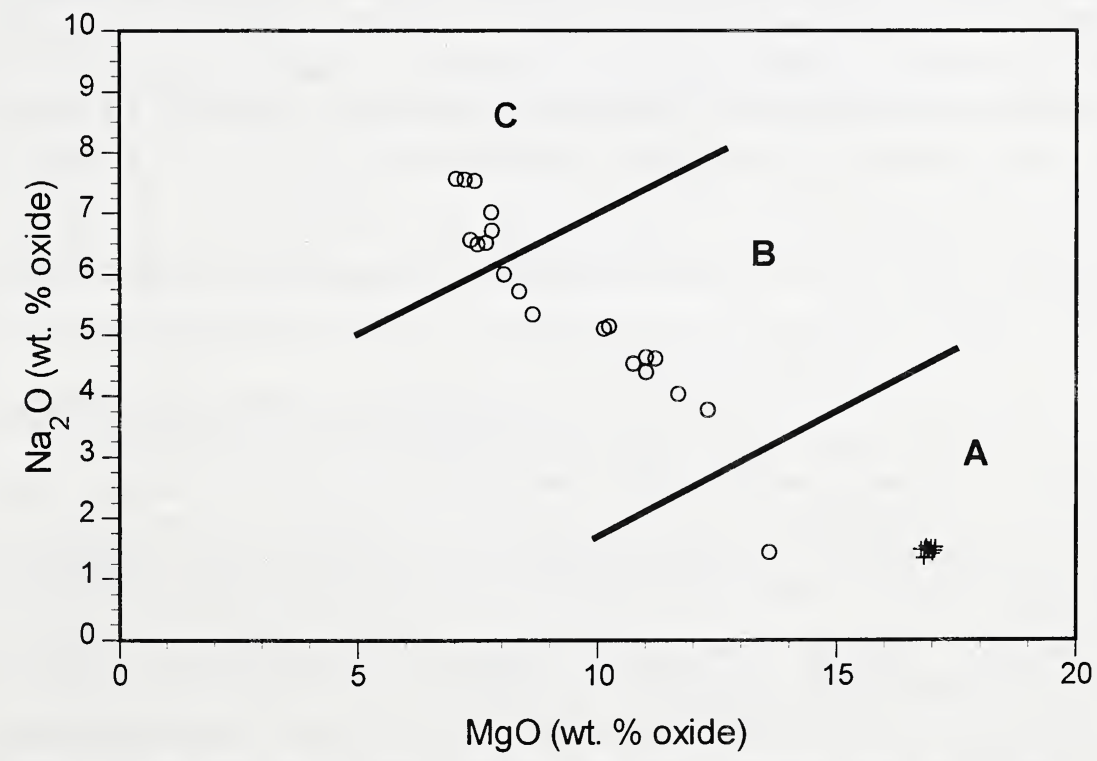

Figure 2: Clinopyroxene from diamondiferous (+) and barren (o) eclogite, compared to Southern African eclogite groups A, B, and C ( Snyder, et al. (1994). 


\section{Relative proportion of diamondiferous eclogites}

A representative sample of 206 small $(8$ to $30 \mathrm{~mm}$ ) eclogites from a heavy mineral concentrate of Jericho kimberlite were examined to estimate the relative proportion of diamondiferous xenoliths among the total eclogite population. From the 206 eclogites, a single diamond-bearing sample was recovered. clearly demonstrating their rarity. Textures were also described for the 206 eclogites, although the small size of the xenoliths relative to crystal dimensions makes the assignments somewhat uncertain. The massive texture occurs in $69(33.5 \%)$ of the examined xenoliths, with the other the other $2 / 3$ being banded or foliated. We randomly selected 20 eclogites for microprobe analysis in order to determine the approximate proportion of eclogites with a diamondiferous chemical signature. One out of these 20 samples has the diamondiferous eclogite chemical signature, implying that (very roughly) $5 \%$ of the eclogites come from the mantle layer that sourced the diamondiferous eclogites. Similar proportions were obtained for randomly selected low-Cr garnet macrocrysts from crushed drill core (14 out of 171 or $8 \%$ ).

Geothermometry

Clinopyroxene-garnet geothermometry (Ellis and Green, 1979) indicates the diamondiferous eclogite formed in a very restricted temperature interval near $1000^{\circ} \mathrm{C}$, in contrast to other eclogites at Jericho which have a calculated temperature range of $850^{\circ}$ to $1060^{\circ} \mathrm{C}$ (Kopylova et al., 1997). The total range of temperature for the diamondiferous eclogites is only $33^{\circ} \mathrm{C}$, which is equivalent to a layer $10 \mathrm{~km}$ thick when projected on to the Jericho peridotite P-T array (Kopylova et al., in press). This layer projects near the base of the petrologic lithosphere between 170 and $180 \mathrm{~km}$ on the peridotite P-T array using the Ellis and Green (1979) geothermometer. Other geothermometers would project onto the peridotite P-T array at different depths, but all agree that Jericho diamondiferous eclogites were derived from a thin mantle layer.

\section{Origin of the diamondiferous eclogite layer}

The restricted chemical signature of diamondiferous eclogites from Jericho indicate that they were derived from a single thin mantle layer, in contrast to barren eclogites at Jericho and diamondiferous eclogites elsewhere (e.g. Udachnaya; Snyder et al., 1997). Mineral chemistry of the diamondiferous eclogites resemble Group A eclogites, and by analogy the protolith may have a mantle origin and have formed as a high-pressure cumulate from a basaltic melt (Shervais et al , 1988). Bulk chemistry of Jericho diamondiferous eclogite is similar to Archean basalt and komatiite (Ireland et. al, 1994). The diamondiferous layer protolith at Jericho was more similar to these rocks than to mid-ocean ridge basalt, as has been proposed for Group A eclogites elsewhere (Ireland et. al, 1994).

\section{References}

Dawson J.B., and Stephens, W.E., 1975, Statistical classification of garnets from kimberlites and associated xenoliths. Journal of Geology, v. 83, p. 589-607.

Ellis, D.J., and Green, D.H., 1979, An experimental study of the effect of Ca upon garnet-clinopyroxene Fe-Mg exchange equilibria. Contributions to Mineralogy and Petrology, v. 71, p. 13-33.

Ireland, T.R., Rudnick, R.L., and Spetsius, Z., 1994. Trace elements in diamond inclusions from eclogites reveal link to Archean granites. Earth and Planetary Science Letters, v. 128, p. 199-213.

Kopylova, M., Russell, J.K. and Cookenboo, H. (in press). Upper mantle stratigraphy of the Slave Craton in Canada: Insights into a new kimberlite province. Geology.

Kopylova, M., Russell, J.K. and Cookenboo, H. (1997). Mantle xenoliths of the Jericho kimberlite: Implications for upper mantle stratigraphy and thermal regime of the Slave Craton, Canada. Ext. Abstract, MIT-Harvard Workshop, 10-14 Oct. 1997.

Snyder, G.A., Taylor, L. A., Crozaz, G., Halliday, A.N., Beard, B. L., Sobolev, V. N., and Sobolev, N.V., 1997. The origins of Yakutian eclogite xenoliths. Journal of Petrology, v. 38, p. 85-113.

Shervais J.W., Taylor, L.A., Lugmair, G.W., Clayton, R.N., Mayeda, T.K., and Korotev, R.L., 1988. Early Proterozoic oceanic crust and the evolution of subcontinental mantle: eclogites and related rocks from southern Africa. Geological Society of America Bulletin, v. 100, p.411-423. 